\title{
Photodynamic therapy of DNA mismatch repair-deficient and -proficient tumour cells
}

\author{
VA Schwarz', R Hornung', A Fedier', MK Fehr', H Walt', U Haller' and D Fink*,' \\ 'Department of Obstetrics and Gynaecology, Division of Gynaecology, University Hospital of Zurich, CH-809I Zurich, Switzerland
}

Loss of DNA mismatch repair is a common finding in hereditary nonpolyposis colon cancer as well as in many types of sporadic human tumours. DNA mismatch repair-deficient cells have been reported to be resistant to many chemotherapeutic agents and to radiotherapy, and to have the potential of rapidly acquiring additional mutations leading to tumour progression. Photodynamic therapy is a new treatment modality using light to activate a photosensitiser that preferentially localises in tumour cells. An oxygen dependent photochemical reaction ensues, resulting in selective tumour necrosis. The effect of loss of DNA mismatch repair activity on the sensitivity to photodynamic therapy was tested using pairs of cell lines proficient or deficient in mismatch repair due to loss of either MLHI or MSH2 protein function. Cells were incubated with the photosensitiser 5, 10,15,20-meta-tetra(hydroxyphenyl)chlorin and exposed to laser light at $652 \mathrm{~nm}$ with various optical doses ranging from $0-1 \mathrm{~J} \mathrm{~cm}^{-2}$. Cell survival was assessed using the clonogenic assay. Loss of MLHI or MSH2 function was not associated with resistance to photodynamic therapy. MCF-7 cells repeatedly treated with photodynamic therapy expressed parental levels of MLHI, MSH2, MSH6, and PMS2. DNA mismatch repair-deficient and -proficient cells showed similar subcellular distributions of meta-tetra(hydroxyphenyl)chlorin as analysed by laser scanning and fluorescence microscopy. Therefore, repeated exposure of tumour cells to photodynamic therapy does not seem to result in loss of DNA mismatch repair, and loss of mismatch repair, in turn, does not seem to contribute to resistance to photodynamic therapy. Our results suggest recommending photodynamic therapy as a strategy for circumventing resistance due to loss of DNA mismatch repair. British Journal of Cancer (2002) 86, I I30- I I35. DOI: 10.1038/sj/bjc/66002 I8 www.bjcancer.com

(C) 2002 Cancer Research UK

Keywords: photodynamic therapy; DNA mismatch repair; drug resistance; m-THPC

DNA mismatch repair (MMR) proteins repair mispaired DNA bases and have an important role in maintaining the integrity of the genome (Modrich, 1997). Loss of MMR is the genetic basis for the hereditary nonpolyposis colon cancer syndrome and is a common finding in a variety of sporadic human tumours. Recent studies have documented that loss of MMR is an important mechanism of resistance to a variety of clinically important drugs, including cisplatin (Aebi et al, 1996; Fink et al, 1996) and the topoisomerase II poisons (Fedier et al, 2001). This is due, in part, to the fact that the MMR system can recognise and bind to various types of adducts in DNA. In addition, the genomic instability that accompanies loss of MMR can increase the rate of mutation in coding or regulatory sequences of other genes whose products may play central roles in determining tumour cell sensitivity to drugs. Loss of MMR has been reported in tumour cell lines selected by repeated treatments for resistance to cisplatin, methylating agents and doxorubicin (Aebi et al, 1996; Brown et al, 1997). Although the reports are controversial there is some evidence that MMR-deficient cells are also resistant to ionising radiation (Fritzell et al, 1997; Xu et al, 2001). The development of drug resistance during chemotherapy of initially chemosensitive tumours is a frequent problem in clinical oncology, since it may lead to tumour progression and finally to the death of the patient. Thus, finding

*Correspondence: D Fink; E-mail: daniel.fink@fhk.usz.ch Received 20 October 200 I; revised 22 January 2002; accepted 24 January 2002 new treatment modalities effective against MMR-deficient tumour cells is of the utmost clinical importance.

Photodynamic therapy (PDT) is being evaluated as an alternative treatment option for chemotherapy-resistant tumours (Canti et al, 1995). PDT uses laser light of appropriate wavelength and energy to activate a systemically applied photosensitiser that concentrates preferentially in malignant tissues. A photochemical reaction ensues, leading to selective tumour necrosis (Dougherty et al, 1975). 5,10,15,20-meta-tetra(hydroxyphenyl)chlorin (m-THPC) is a neutral lipophilic second-generation photosensitiser with an absorption maximum at $652 \mathrm{~nm}$. Confocal laser scanning fluorescence microscopy studies of $\mathrm{m}$-THPC in vitro have shown a diffuse distribution of the drug in the cytoplasm (McNair et al, 1997). Although there is no localisation of the photosensitiser within the nucleus, a low level of potentially mutagenic DNA damage could occur, depending on the photosensitiser, the cellular repair mechanisms and the affected genes (Oleinick and Evans, 1998). Indeed, PDT has been reported to result in DNA lesions such as single-strand breaks and alkali-labile sites, DNA protein crosslink-correlation and DNA degradation as well as in chromosome aberrations (Evans et al, 1997; Oleinick and Evans, 1998). One major advantage of PDT over other treatment modalities is that it can be safely repeated several times (Hornung et al, 1998). Moreover, PDT has been reported to be effective in multi-drug resistant cell lines (Canti et al, 1995).

In the current study, we sought to determine whether loss of MMR affects the sensitivity of tumour cells to PDT. We report 
here that loss of MMR does not contribute to resistance to PDT and that repeated exposure of cells to PDT in turn, does not result in loss of MMR, meaning that PDT can be recommended for use in tumours deficient in MMR.

\section{MATERIALS AND METHODS}

\section{Cell lines}

The MLH1-deficient human colorectal adenocarcinoma cell line HCT116 was obtained from the American Tissue Culture Collection (ATCC CCL 247, Manassas, VA, USA). Sublines complemented with chromosome 3 (clone HCT116/3-6, identified here as HCT116+ch3) or chromosome 2 (clone HCT116/2-1, identified here as HCT116+ch2) were obtained from Drs CR Boland and M Koi (Koi et al, 1994) as were the MSH2-deficient human endometrial adenocarcinoma cell line HEC59 and a subline complemented with chromosome 2 (HEC59+ch2). HCT116 cells contain a hemizygous mutation in MLH1 resulting in a truncated, nonfunctional protein (Boyer et al, 1995). Parental HEC59 cells have been shown to contain a frameshift mutation in one allele and a truncating mutation in the second allele of MSH2 and to be deficient in repair activity (Umar et al, 1997). The chromosome-complemented sublines HCT116+ch3 and HEC59+ch2 are competent in MMR. Both cell lines were grown in Iscove's modified Dulbecco's medium (Life Technologies, Basel, Switzerland) supplemented with $2 \mathrm{mM}$ L-glutamine and $10 \%$ heat-inactivated foetal bovine serum (GIBCO, Basel, Switzerland). Geneticin $\left(400 \mu \mathrm{g} \mathrm{ml}^{-1}\right.$ for HCT116+ch2 and HCT116+ch3 and $600 \mu \mathrm{g} \mathrm{ml}^{-1}$ for HEC59+ch2) (Life Technologies) was added to medium to maintain the chromosome-complemented lines, but all the experiments were carried out in its absence. The absence and presence of expression of MLH1 in HCT116+ch2 and HCT116+ch3 as well as expression of MSH2 in HEC59 and HEC59+2 were verified by immunoblot analysis (data not shown). The oestrogen dependent human breast cancer cell line MCF-7, proficient in MMR, was cultured in Opti-MEM (GIBCO) supplemented with $10 \%$ foetal bovine serum, $25 \mathrm{IE} \mathrm{ml}^{-1}$ penicillin (GIBCO) and $25 \mathrm{mg} \mathrm{ml}^{-1}$ streptomycin (GIBCO). The cell lines tested negative for contamination with Mycoplasma spp and cultured as monolayers in a $95 \%$ air $/ 5 \% \quad \mathrm{CO}_{2}$ atmosphere at $37^{\circ} \mathrm{C}$. All cell lines used in the experiments form well-defined individual colonies when seeded sparsely on standard tissue culture plates.

\section{Reagents}

The porphyrin-based photosensitiser 5,10,15,20-meta-tetra (hydroxyphenyl)chlorin (m-THPC, Foscan ${ }^{\mathbb{R}}$ ) with a molecular weight of 680 Daltons was provided by SCOTIA Pharmaceuticals Ltd (Stirling, UK). This second-generation photosensitiser has recently been approved by the European Medicine Evaluation Agency for treatment of head and neck cancer. The absorption maximum of $\mathrm{m}$-THPC is at $652 \mathrm{~nm}$. m-THPC was dissolved in a recommended solution of ethanol:polyethylene-glycol: water $(20: 30: 50)$ to a concentration of $5 \mathrm{mg}$ per $10 \mathrm{ml}$, and stored at $4{ }^{\circ} \mathrm{C}$ in the dark. 6-Thioguanine was purchased from Sigma (Buchs, Switzerland) and dissolved immediately before use in $0.9 \%$ saline.

\section{PDT experiments}

PDT experiments were carried out under dimmed room light as follows. Cells growing in log phase were harvested with EDTAtrypsin and washed with phosphate-buffered saline (PBS). Either 2000 MLH1-proficient or -deficient cells (HCT116), or 10000 MSH2-proficient or -deficient cells (HEC59) from a single-cell suspension were seeded into $60 \mathrm{~mm}$ tissue culture dishes. After $24 \mathrm{~h}, 0.1 \mu \mathrm{g} \mathrm{ml}^{-1} \mathrm{~m}$-THPC diluted in tissue culture medium was added to the dishes and cells were incubated with $\mathrm{m}$-THPC for $24 \mathrm{~h}$. Cells not exposed to either m-THPC or laser light were used as controls. Then, cells were exposed to laser light at a wavelength of $652 \mathrm{~nm}$ generated by a diode laser (Applied Optronics Corp., South Plainfield, NJ, USA) and an energy of $25 \mathrm{~mW}$ as verified by a power meter (Fieldmaster Coherent Inc., Santa Clara, USA). The light was conducted through a laser fibre terminated by a front lens light diffuser to the site of irradiation. The optical dose $\left(\mathrm{J} \mathrm{cm}^{-2}\right)$ is defined as the fluence rate $\left(\mathrm{W} \mathrm{cm}^{-2}\right)$ multiplied by the exposure time in seconds. Irradiation times for the colorectal and the endometrial cancer cells were $0,7,14,28,42$ or $56 \mathrm{~s}$, resulting in optical doses of $0,0.125,0.25,0.5,0.75$ or $1 \mathrm{~J} \mathrm{~cm}^{-2}$ at a fluence rate of $36 \mathrm{~mW} \mathrm{~cm} \mathrm{~cm}^{-2}$. The cells were then washed, fresh medium was added and the cells were allowed to proliferate for 10 days.

\section{Repetitive PDT exposure of MCF-7 cells}

MCF-7 breast cancer cells $\left(10^{6}\right)$ growing in log phase were seeded into $60 \mathrm{~mm}$ tissue culture dishes. After $24 \mathrm{~h}, \mathrm{~m}$-THPC was added to a final concentration of $0.1 \mu \mathrm{g} \mathrm{ml}^{-1}$ and incubated for $24 \mathrm{~h}$ in the dark, followed by illumination for $5 \mathrm{~min}$ with a fluence rate of $25 \mathrm{~mW} \mathrm{~cm}^{-2}$ resulting in an optical dose of $2.12 \mathrm{~J} \mathrm{~cm}^{-2}$. This PDT dose resulted in a survival fraction of approximately $10^{-4}$. Surviving cells were allowed to proliferate to a density of $10^{6}$ cells, and the experiment was repeated for a total of five times. The repetition was restricted to five times due to the fact that from the clinician's point of view it is very unlikely that recurrent tumours will be treated more than five times with the same treatment modality.

\section{Clonogenic assay}

Cell survival was assessed by means of the clonogenic assay 10 days after PDT exposure. Cells were fixed with $25 \%$ acetic acid in ethanol and stained with Giemsa. Colonies of at least 50 cells were scored visually. Each experiment was performed at least three times using triplicate cultures for each optical dose. Cell survival was expressed as a fraction of treated to untreated cells (survival fraction, SF) at a relative plating efficiency of $0.5 \%$ for the HCT116 and $0.3 \%$ for the HEC59 cell lines.

\section{Immunoblot analysis}

Parental and PDT-treated MCF-7 cells were harvested as described before and lysed on ice in $150 \mathrm{~mm} \mathrm{NaCl}$ containing $5 \mathrm{~mm}$ EDTA, $1 \%$ Triton X-100, $10 \mathrm{~mm}$ Tris/ $\mathrm{HCl}(\mathrm{pH} 7.4), 5 \mathrm{~mm}$ dithiothreitol, $0.1 \mathrm{~mm}$ phenylmethylsulphonyl fluoride and $1 \mu \mathrm{g} \mathrm{ml}^{-1}$ aprotinin, followed by centrifugation at $14000 \mathrm{~g}$ for $20 \mathrm{~min}$ at $4^{\circ} \mathrm{C}$. The protein amount was determined using the Bio-Rad protein assay dye (Bio-Rad, Glattbrugg, Switzerland). After centrifugation, $50 \mu \mathrm{g}$ protein were denaturated by boiling at $95^{\circ} \mathrm{C}$ for $5 \mathrm{~min}$ in an equal volume of $130 \mathrm{~mm}$ Tris/HCl ( $\mathrm{pH}$ 6.8) containing $20 \%$ glycerol, $4.6 \%$ sodium dodecyl sulphate (SDS) and $0.02 \%$ bromophenol blue. The proteins were separated using SDS-PAGE on a 7.5\% gel followed by blotting onto a polyvinylidene difluoride membrane (Amersham Pharmacia Biotech, Buckinghamshire, UK). The MMR proteins were detected using anti-MLH1 (clone G168-728, PharMingen, Heidelberg, Germany), anti-MSH2 (clone FE11, Calbiochem, Lucerne, Switzerland), anti-MSH6 (provided by Dr J Jiricny) and anti-PMS2 (clone A16-4, PharMingen). $\beta$ tubulin was used as a loading control. The monoclonal antibody G168-728 was generated with a full-length MLH1 protein, whereas clone FE11 is a mouse monoclonal antibody generated with a carboxyl-terminal fragment of the $\mathrm{MSH} 2$ protein. The polyclonal anti-MSH6 is directed against the full-length protein. The monoclonal antibody A16-4 was prepared with a carboxyl-terminal fragment of the PMS2 protein. After washing the blots, horseradish peroxidase-conjugated antimouse antibody (Amersham Life 
Science, Buckinghamshire, UK) was added, and the complexes were visualised by enhanced chemiluminescence (Amersham Life Science).

\section{Subcellular drug distribution and kinetics of drug uptake}

A confocal laser scanning microscope (Leica TCS 4D, Glattbrugg, Switzerland) equipped with an Argon Krypton laser was used to investigate subcellular photosensitiser distribution. HCT116+ch2 and HCT116+ch3 cells were grown on cover slides and incubated for $24 \mathrm{~h}$ with $0.1 \mu \mathrm{g} \mathrm{ml}^{-1} \mathrm{~m}$-THPC. The dye was excited at $488 \mathrm{~nm}$ and fluorescence was detected above $590 \mathrm{~nm}$ with a longpass filter. Kinetics of drug uptake were studied using a fluorescence microscope (Leitz DMRBE, Leica, Glattbrugg, Switzerland) equipped with a computer-controlled charge coupled device camera (Photometrics Ltd., Tucson, AZ, USA). A 530 out of $595 \mathrm{~nm}$ bandpass filter and a $615 \mathrm{~nm}$ longpass filter were used for excitation and for detection of emission, respectively. Five micrographs per slide were taken and two cells per picture were analysed. Fluorescence intensity was quantified (counts per pixel) as a function of the incubation time using IPLab Spectrum software (Scanalytics, Fairfax, VA, USA). Experiments were repeated five times.

\section{Statistical analysis}

Mean \pm s.d. values were calculated for all data sets. The two-sided paired $t$-test was used to compare the effect of loss of MLH1 or $\mathrm{MSH} 2$ on PDT sensitivity. $\mathrm{IC}_{50}$-values were calculated by log-linear interpolation. $P<0.05$ was considered to be a statistically significant difference.

\section{RESULTS}

\section{Clonogenic cell survival after PDT}

A point investigated was whether the sensitivity of tumour cells to PDT is affected by the MMR status. 6-Thioguanine, to which repair-deficient cells were, as expected, 4.2- (IC 50 ; HCT116+ch2) and 5.6-fold $\left(\mathrm{IC}_{50}\right.$; HEC59) more resistant than the repair-proficient sublines, was included as a control. Figure 1 shows the survival curves for the MLH1-deficient HCT116+ch2 and the MSH2-deficient HEC59 cells as well as the respective repair-proficient HCT116+ch3 and HEC59+ch2 cell lines after PDT as a function of the optical dose $\left(\mathrm{J} \mathrm{cm}^{-2}\right)$. The optical dose required to induce cell death in $50 \%$ of all cells $\left(\mathrm{IC}_{50}\right)$ was $0.32 \pm 0.03 \mathrm{~J} \mathrm{~cm}^{-2}$ for the
HCT $116+\mathrm{ch} 2$ and $0.39 \pm 0.20 \mathrm{~J} \mathrm{~cm}^{-2}$ for the HCT116+ch3 cells $(P=0.57)$. Likewise, MSH2-deficient tumour cells showed no altered sensitivity to PDT. The corresponding $\mathrm{IC}_{50}$-values were $0.54 \pm 0.06 \mathrm{~J} \mathrm{~cm}^{-2}$ for the MMR-deficient HEC59 and $0.46 \pm 0.17 \mathrm{~J} \mathrm{~cm}^{-2}$ for the repair-proficient HEC59+ch2 cells $(P=0.24)$. Thus, loss of MMR does not result in resistance to PDT.

\section{MMR protein expression in MCF-7 cells after repetitive PDT exposure}

The question was addressed as to whether repetitive treatments with PDT result in de novo loss of expression of MMR proteins in the parental human breast cancer MCF-7 cells. These cells express MLH1, PMS2, MSH2, and MSH6 in amounts that are readily detectable by immunoblot, and they have previously been reported to be sensitive to PDT (Hornung et al, 1998). Expression of MMR proteins in MCF-7 cells after five subsequent exposures to PDT and in untreated MCF-7 cells was determined by immunoblot analyses. Figure 2 shows that MCF-7 cells repeatedly treated with PDT express parental levels of MLH1, MSH2, MSH6 and PMS2. The sensitivity of the MCF-7 cells after five PDT treatments was similar to that of MCF-7 cells after a single exposure. Therefore, repeated exposure of tumour cells to PDT does not result in loss of MMR proteins.

\section{Kinetics of drug uptake and subcellular photosensitiser distribution}

The kinetics of uptake of m-THPC $\left(0.1 \mu \mathrm{g} \mathrm{ml}^{-1}\right)$ were studied in the MMR-deficient HCT116+ch2 and -proficient HCT116+ch3 cells by measuring the photosensitiser-mediated fluorescence intensity (counts per pixel, arbitrary unit) as a function of the incubation time. Figure 3 shows that m-THPC-mediated fluorescence intensity markedly increased within $24 \mathrm{~h}$ and reached a plateau with highest fluorescence intensity at $34 \mathrm{~h}$ after incubation in MLH1-proficient as well as in MLH1-deficient cells. Thus, mTHPC uptake occurs within $24 \mathrm{~h}$ and follows similar kinetics in both cell lines.

The subcellular distribution of m-THPC was analysed by confocal laser scanning microscopy. m-THPC-mediated fluorescence intensity in the cytoplasm of HCT116 cells increased within $24 \mathrm{~h}$ after administration. At that time, only weak fluorescence intensity was associated with the nuclear membrane. Figure 4 represents a typical example of fluorescence distribution in the HCT116+ch3 (Figure 4A) and HCT116+ch2 (Figure 4B) cell lines after $24 \mathrm{~h}$ of $\mathrm{m}$-THPC administration,

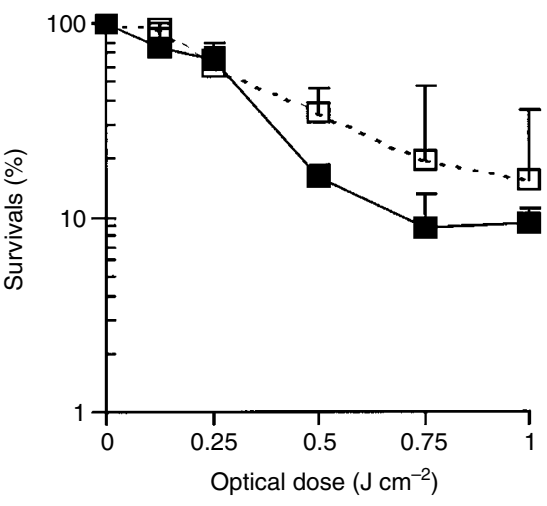

$\mathrm{HCT} 116+\mathrm{ch} 2$ $\square \mathrm{HCT} 116+\mathrm{ch} 3$

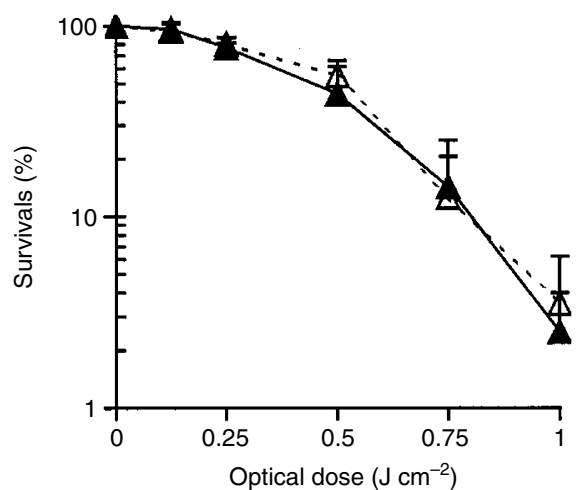

$\triangle \mathrm{HEC} 59$

$\Delta \mathrm{HEC} 59+\mathrm{ch} 2$

Figure I Clonogenic survival curves for PDT for the MLHI-deficient and-proficient colon carcinoma cell lines and the MSH2-deficient and -proficient endometrial carcinoma cell lines. Each point represents the mean \pm s.d. of at least three experiments performed in triplicate. 


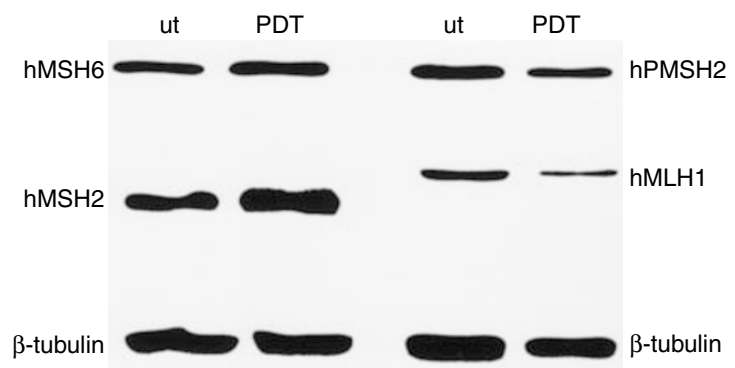

Figure 2 Immunoblot of untreated MCF-7 cells (ut) and MCF-7 cells after five subsequent PDT exposures (PDT). MCF-7 cells repeatedly treated with PDT express parental levels of MLHI, MSH2, MSH6 and PMS2. $\beta$-tubulin was used as a loading control.

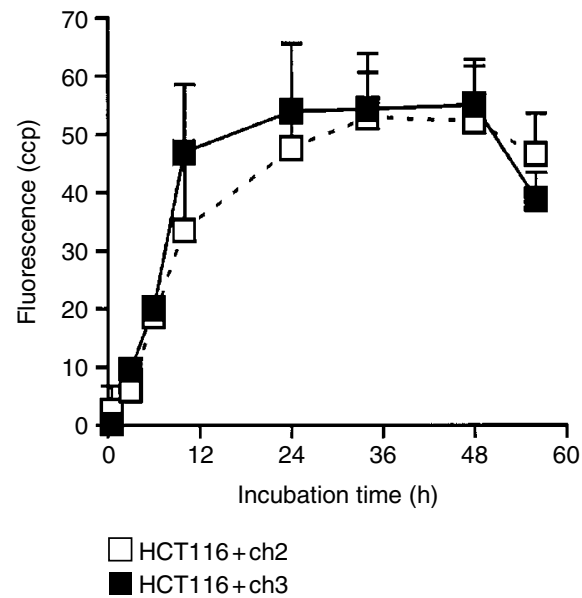

Figure 3 Photosensitiser-mediated fluorescence intensity (counts per pixel, cpp) for MLHI-deficient and -proficient tumour cells shown as a function of incubation time. Each point represents the mean \pm s.d. of six experiments.
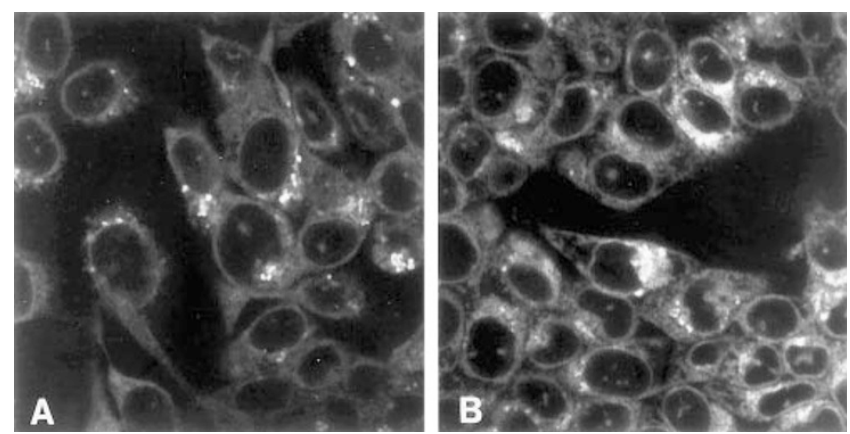

Figure 4 Bright field image of HCTI I6+ch3 (A) and HCTI I 6+ch2 (B) after incubation with $0.1 \mu \mathrm{g} \mathrm{ml} \mathrm{m}^{-1} \mathrm{~m}$-THPC for $24 \mathrm{~h}$. After $24 \mathrm{~h}$ of incubation there was no detectable fluorescence within the nucleus. The nuclear membrane is distinctly stained in both cell lines.

demonstrating that the fluorescence pattern of HCT116+ch3 was similar to that of HCT116+ch2 cells. Likewise, longer incubation with $\mathrm{m}$-THPC resulted in increased fluorescence intensity associated with membranous structures in the cytoplasm, whereas the nucleus did not show detectable fluorescence at any time after photosensitisation. Thus, drug uptake kinetics and subcellular distributions are very similar in MMR-proficient and -deficient cells.

\section{DISCUSSION}

MLH1 or MSH2-deficient tumour cells have been reported to be resistant to a large number of anticancer drugs (Aebi et al, 1997; Fink et al, 1998b) and to radiotherapy (Fritzell et al, 1997; Xu et al, 2001), and as a result, MMR status may be an important resistance factor. Although loss of MMR results in relatively small degrees of resistance, there is evidence that this resistance is nevertheless of substantial clinical significance. The strongest clinical evidence correlating chemotherapy responses with the in vitro data has been reported from studies on ovarian and breast cancers. We and others (Brown et al, 1997; Fink et al, 1998a; Samimi et al, 2000) have shown that there is an increase in the number of ovarian tumour cells that score negative for MLH1 expression following platinum-based chemotherapy when compared with untreated tumours. Recently, studies have correlated tumour response and poor disease-free survival with loss of MLH1 expression in breast cancer tumours following anthracycline-based neoadjuvant chemotherapy (Mackay et al, 2000). These observations support the concept of in vivo enrichment of a subpopulation of MMRdeficient cells in response to treatment, which are more likely to be drug resistant, have a mutator phenotype and consequently, an adverse effect on prognosis. Similarly, it has been reported that low levels of MLH1 and MSH2 in malignant gliomas correlate with resistance to temozolomide, a methylating agent (Friedman et al, 1998).

PDT is a relatively new treatment modality for malignant tumours. Selective tumour cell necrosis is induced by a distinct photochemical mechanism. While chemoresistance in MMR-deficient tumours seems to force physicians to surrender an efficient anticancer treatment, the present study suggests that PDT might offer a future treatment option for these patients. So far, it has been reported that PDT does not induce resistance to chemo- or radiotherapy, and that this treatment can be repeated without increasing toxicity and with low probability of inducing resistance to PDT (Sharkey et al, 1993; Luna et al, 1995; Hornung et al, 1998; Singh et al, 2001). Our study extends the theoretical advantages to conventional treatment modalities for cancer by demonstrating that loss of MMR does not result in resistance to PDT.

Loss of MMR has been reported in tumour cells selected by repeated treatments with cisplatin, methylating agents or doxorubicin (Aebi et al, 1996; Brown et al, 1997). Therefore, we analysed by immunoblot the presence of the MMR proteins in MCF-7 cells that survived five subsequent cycles of PDT. As shown in Figure 2, the PDT-treated MCF-7 cells expressed parental levels of MLH1, MSH2, MSH6 and PMS2. Thus, PDT is not only effective against MMR-deficient cells but - unlike some chemotherapeutic agents it does not result in loss of MMR, allowing standard chemo- or radiotherapy following PDT-mediated tumour treatment.

PDT-induced cell killing is not fully understood and may depend on the photosensitiser and the treatment protocol used. However, the potential of PDT to induce genotoxic damage seems to be relatively low compared with ionising radiation or chemotherapy (Evans et al, 1997). This may, in part, be explained as follows. As demonstrated in Figure 4, the cationic and lipophilic photosensitiser m-THPC localises in cellular membranes, mainly in the mitochondria with highly negative electrochemical potential of the inner membrane, and to a lower extent in the nuclear membrane. Singlet oxygen, the major mediator of the PDTinduced photochemical reaction (Henderson and Dougherty, 1992), has a very short diffusion distance of $0.01 \mu \mathrm{m}$ and a very short lifetime of $0.01 \mu \mathrm{s}$ (Moan and Berg, 1991). The photochemical reaction may therefore reach only DNA that is located very close to the nuclear membrane (Evans et al, 1997). Oxidative damage leading to single-strand breaks and alkali-labile sites, DNA-protein crosslinks and DNA degradation, as well as to chromosome aberrations has been reported (Evans et al, 1997; Oleinick 
and Evans, 1998). These lesions, however, are likely to be relatively easily repaired (McNair et al, 1997). Considering that MMR seems not to be affected by PDT, it is reasonable to assume that PDTinduced DNA damage remains of low clinical importance. Indeed, the risk of PDT generating secondary cancer is known to be very small (Moan and Berg, 1992).

In order to ensure that PDT acts similarly in MMR-proficient and -deficient tumour cells, the subcellular photosensitiser distribution and kinetics of drug uptake (i.e. relative values representing changes in drug concentrations) have been estimated using fluorescence microscopy. As demonstrated in Figures 3 and 4, both, drug uptake kinetics and drug distribution, were similar in MMR-proficient and -deficient cells. This finding further supports the idea that PDT-mediated cell killing is fully independent of MMR. Furthermore, the pattern of the subcellular photosensitiser distribution and the kinetics of drug uptake in HCT116 cells are in good agreement with previous findings of this laboratory in MCF-7 and V-79 cells that are known to be proficient in MMR (Hornung et al, 1997).

The addition of mitomycin $C$ has been shown to enhance the PDT effect (Nahabedian et al, 1988). Recently, it has been reported that loss of MMR is specifically associated with hypersensitivity to

\section{REFERENCES}

Aebi S, Fink D, Gordon R, Kim HK, Zheng H, Fink JL, Howell SB (1997) Resistance to cytotoxic drugs in DNA mismatch repair-deficient cells. Clin Cancer Res 3: $1763-1767$

Aebi S, Kurdi-Haidar B, Gordon R, Cenni B, Zheng H, Fink D, Christen RD, Boland CR, Koi M, Fishel R, Howell SB (1996) Loss of DNA mismatch repair in acquired resistance to cisplatin. Cancer Res 56: $3087-3090$

Boyer JC, Umar A, Risinger JI, Lipford JR, Kane M, Yin S, Barett JC, Kolodner RD, Kunkel TA (1995) Microsatellite instability, mismatch repair deficiency, and genetic defects in human cancer cell lines. Cancer Res 55: 6063-6070

Brown R, Hirst GL, Gallagher WM, McIlwrath AJ, Margison GP, van der Zee AG, Anthoney DA (1997) hMLH1 expression and cellular responses of ovarian tumor cells to treatment with cytotoxic anticancer agents. Oncogene 15: $45-52$

Canti G, Lattuada D, Morelli S, Nicolin A, Cubeddu R, Taroni P, Valentini G (1995) Efficacy of photodynamic therapy against doxorubicin-resistant murine tumors. Cancer Lett 93: 255-259

Dougherty TJ, Grindey GB, Fiel R, Weishaupt KR, Boyle DG (1975) Photoradiation therapy. II. Cure of animal tumors with hematoporphyrin and light. J Natl Cancer Inst 55: 115-121

Evans HH, Horng MF, Ricanati M, Deahl JT, Oleinick NL (1997) Mutagenicity of photodynamic therapy as compared to UVC and ionizing radiation in human and murine lymphoblast cell lines. Photochem Photobiol 66: $690-696$

Fedier A, Schwarz VA, Walt H, Carpini RD, Haller U, Fink D (2001) Resistance to topoisomerase poisons due to loss of DNA mismatch repair. Int Cancer 93: $571-576$

Fink D, Nebel S, Aebi S, Zheng H, Cenni B, Nehme A, Christen RD, Howell SB (1996) The role of DNA mismatch repair in platinum drug resistance. Cancer Res 56: $4881-4886$

Fink D, Nebel S, Norris PS, Baergen RN, Wilczynski SP, Costa MJ, Haas M, Cannistra SA, Howell SB (1998a) Enrichment for DNA mismatch repairdeficient cells during treatment with cisplatin. Int J Cancer 77: 741-746

Fink D, Nebel S, Norris PS, Aebi S, Kim HK, Haas M, Howell SB (1998b) The effect of different chemotherapeutic agents on the enrichment of DNA mismatch repair-deficient tumour cells. Br J Cancer 77: 703-708

Fiumicino S, Martinelli S, Colussi C, Aquilina G, Leonetti C, Crescenzi M, Bignami M (2000) Sensitivity to DNA cross-linking chemotherapeutic agents in mismatch repair-defective cells in vitro and in xenografts. Int J Cancer 85: $590-596$

Friedman H, McLendon R, Kerby T, Dugan M, Bigner SH, Henry AJ, Ashley DM, Krischer J, Lovell S, Rasheed K, Marchev F, Seman AJ, Cokgor I, Rich J, Stewart E, Colvin OM, Provenzale JM, Bigner DD, Haglund MM, Friedman AH, Modrich PL (1998) DNA mismatch repair and $\mathrm{O}_{6}$-alkylguanineDNA alkyltransferase analysis and response to temodal in newly diagnosed malignant glioma. J Clin Oncol 16: $3851-3857$ mitomycin C (Fiumicino et al, 2000). Although mechanistic studies are needed to fully elucidate the biochemical events involved, these findings are interesting because they may suggest a means of selectively eliminating cells that have lost their ability to perform MMR.

In conclusion, our results demonstrate that: (i) PDT is as efficient in MMR-deficient cells as in MMR-proficient cells; (ii) repetitive treatments with PDT do not result in loss of MMR; and (iii) MMR-deficient cells show similar m-THPC distribution and kinetics of drug uptake as cells proficient in MMR. Thus, our results suggest the use of PDT as a strategy for circumventing resistance due to loss of MMR.

\section{ACKNOWLEDGEMENTS}

The authors are grateful to Dr J Jiricny (Institute of Medical Radiobiology of the University of Zurich, Switzerland) for providing the antibodies and Aida Kurmanaviciene for technical support. We also thank Drs CR Boland and M Koi for kindly providing the cell lines. This work has been supported in part by a grant from the Swiss National Science Foundation (No. 31-52531.97) and by Scotia Pharmaceuticals Ltd. (Stirling, UK).
Fritzell JA, Narayanan L, Baker SM, Bronner CE, Andrew SE, Proll TA, Bradley A, Jirik FR, Liskay RM, Glazer PM (1997) Role of DNA mismatch repair in the cytotoxicity of ionizing radiation. Cancer Res 57: 5143-5147

Henderson BW, Dougherty TJ (1992) How does photodynamic therapy work?. Photochem Photobiol 55: $145-157$

Hornung R, Jentsch B, Crompton NE, Haller U, Walt H (1997) In vitro effects and localisation of the photosensitizers $\mathrm{m}$-THPC and $\mathrm{m}$-THPC MD on carcinoma cells of the human breast (MCF-7) and Chinese hamster fibroblasts (V-79). Lasers Surg Med 20: 443-450

Hornung R, Walt H, Crompton NE, Keefe KA, Jentsch B, Perewusnyk G, Haller U, Kochli OR (1998) m-THPC-mediated photodynamic therapy (PDT) does not induce resistance to chemotherapy, radiotherapy or PDT on human breast cancer cells in vitro. Photochem Photobiol 68: $569-574$

Koi M, Umar A, Chauhan DP, Cherian SP, Carethers JM, Kunkel T, Boland CR (1994) Human chromosome 3 corrects mismatch repair deficiency and microsatellite instability and reduces $\mathrm{N}$-methyl- $\mathrm{N}^{\prime}$-nitro- $\mathrm{N}$-nitrosoguanidine tolerance in colon tumor cells with homozygous hMLH1 mutation. Cancer Res 54: 4308-4312

Luna MC, Ferrario A, Rucker N, Gomer CJ (1995) Decreased expression and function of alpha-2 macroglobulin receptor/low density lipoprotein receptor-related protein in photodynamic therapy-resistant mouse tumor cells. Cancer Res 55: $1820-1823$

Mackay HJ, Cameron D, Rahilly M, Mackean MJ, Paul J, Kaye SB, Brown R (2000) Reduced MLH1 expression in breast tumors after primary chemotherapy predicts disease-free survival. J Clin Onco 18: 87-93

McNair FI, Marples B, West CM, Moore JV (1997) A comet assay of DNA damage and repair in K562 cells after photodynamic therapy using haematoporphyrin derivative, methylene blue and meso-tetrahydroxyphenylchlorin. Br J Cancer 75: 1721-1729

Moan J, Berg K (1991) The photodegradation of porphyrins in cells can be used to estimate the lifetime of singlet oxygen. Photochem Photobiol 53: $549-553$

Moan J, Berg K (1992) Yearly review; Photochemotherapy of cancer: Experimental research. Photochem Photobiol 55: $931-948$

Modrich P (1997) Strand-specific mismatch repair in mammalian cells. J Biol Chem 272: $24727-24730$

Nahabedian MY, Cohen RA, Contino MF, Terem TM, Wright WH, Berns MW, Wile AG (1988) Combination cytotoxic chemotherapy with cisplatin or doxorubicin and photodynamic therapy in murine tumors. J Natl Cancer Inst 80: $739-743$

Oleinick NL, Evans HH (1998) The photobiology of photodynamic therapy: cellular targets and mechanisms. Radiat Res 150: $146-156$ 
Samimi G, Fink D, Varki NM, Husain A, Hoskins WJ, Alberts DS, Howell SB (2000) Analysis of MLH1 and MSH2 expression in ovarian cancer before and after platinum drug-based chemotherapy. Clin Cancer Res 6: $1415-$ 1421

Sharkey SM, Wilson BC, Moorehead R, Singh G (1993) Mitochondrial alterations in photodynamic therapy-resistant cells. Cancer Res 53: 4994-4999

Singh G, Espiritu M, Shen XY, Hanlon JG, Rainbow AJ (2001) In vitro induction of PDT resistance in HT29, HT1376 and SK-N-MC cells by various photosensitizers. Photochem Photobiol 73: 651-656
Umar A, Koi M, Risinger JI, Glaab WE, Tindall KR, Kolodner RD, Boland CR, Barrett JC, Kunkel TA (1997) Correction of hypermutability, Nmethyl-N'-nitro-N-nitrosoguanidine resistance, and defective DNA mismatch repair by introducing chromosome 2 into human tumor cells with mutations in MSH2 and MSH6. Cancer Res 57: 3949-3955

Xu XS, Narayanan L, Dunklee B, Liskay RM, Glazer PM (2001) Hypermutability to ionizing radiation in mismatch repair-deficient Pms2 knockout mice. Cancer Res 61: 3775-3780 